\title{
Three Concentric Tube Heat Exchange With NTU-Effective Method
}

\author{
Liyun Arun Hutagalung \\ Faculty Of Engineering, University Of North Sumatra, Jl. Dr. Mansur No. 9 Padang Bulan, Kec. Medan Baru, \\ Kota Medan 20222
}

\begin{abstract}
ARTICLE INFO
Article history:

Received Aug 10, 2021

Revised Sep 21, 2021

Accepted Oct 30, 2021

Keywords:

Heat Exchanger

Double Concentric Pipe Triple Concentric Pipe

ABSTRACT

Heat exchanger is an exchange device with three concentric pipe tubes with direct flow used to reduce hot fluid to cold fluid using cold water fluid. the research was carried out triple pipes that flowed in the same direction with 3 variationsin the temperature pipe of the hot water fluid th with a temperature of $50 \mathrm{oC}, 55 \mathrm{oC}$ and $60 \mathrm{oC}$ with temperature of cold water fluid tc $250 \mathrm{C}$ and this study used a flow rate of $0.000025 \mathrm{~m} 3 / \mathrm{s}=$ $0.000033 \mathrm{~m} 3 / \mathrm{s}$ and $0.000041 \mathrm{~m} 3 / \mathrm{s}$. The results of this study showed that the equilibrium temperature obtained from the experimental results of the effectiveness of the one-way pipeline flow was $1=32.99 \%$ the effectiveness of thr second channel pipe of $2=66.48 \%$ and ont the effectiveness of the third channel pipe of $3=33.57 \%$ 3rd data with a debut of $0.000025 \mathrm{~m} 3 / \mathrm{s}$ and the effectiveness of the opposite flow the channel one pipe is $1=55.16 \%$ on the effectiveness of the second channel pipe of $2=66.48 \%$ and on the effectiveness of the third channel pipe of $3=60.59 \%$ it is obtained in the with to 7 with a discharge of $0.000041 \mathrm{~m} 3 / \mathrm{s}$.
\end{abstract}

access article under the CC BY-NC license.

\section{Corresponding Author:}

Liyun Arun Hutagalung,

Faculty Of Computer Science And Information Technology,

University Of North Sumatra,

JI. Dr. Mansur No. 9 Padang Bulan, Kec. Medan Baru, Kota Medan 20222.

Email : liyunhutagalung@gmail.com

\section{INTRODUCTION}

Heat exchangers are used to transfer heat from one liquid to another. The basic component of a heat exchanger can be seen as a tube with one fluid flowing through the tube. The simple context of a heat exchanger is that one hot fluid and one cold fluid move in the same direction in a concentric tube construction in parallel with the inflow and outflow being the same in the same direction. Many researchers have carried out the analysis of double tube heat exchangers. The research has conducted theoretical and experimental analysis of three concentric tubes of triple concentric tube heat exchanger (TCTHE). A set of equations for the design and performance analysis of concentric pipes has been developed. The equation developed for dissipating heat to the surrounding circle is useful for design purposes.

The heat exchanger is widely used by TCHE by Unal A [1]. In the first part the differential equation governing the equation developed together with possible solutions under simplified conditions for the parallel flow regulator the equation derived in his study can be used to determine the temperature variation along the exchanger. . 
Batmaz E [2] developed a more generic way of calculating the overall heat transfer with the fluid temperature of the triple heat exchanger tube for this current flow regulation using the energy balance equation on the control volume. By comparing the overall effective heat transfer coefficient and the effectiveness values for the TCHE equivalent to a (theoretical) double tube heat exchanger.

The heat exchanger is very influential in the industry on the success of the entire process series, because the failure of the operation of this tool either due to mechanical or operational failure can cause the unit operation to stop. So a heat exchanger (heat exchanger) is required to have good performance in order to obtain maximum results and can fully support an operational unit. One of the performance characteristics of this heat exchanger is the effectiveness of the heat exchanger

In this test the heat exchanger used is a three-layer tube type heat exchanger (triple concentric heat exchanger) with copper base material, this triple concentric heat exchanger type has advantages compared to other types of heat exchangers, namely the ease of this tool to be opened and removed from the heat exchanger. the assembly to allow for better and easier cleaning and maintenance. Apart from that, this tool is also suitable for use with liquid fluids, because it has a wavy heat transfer surface that causes the turbulence of the fluid flow to be higher and automatically the heat transfer that occurs will be more effective.

\section{RESEARCH METHOD}

The writing methodology used in writing this thesis is as follows:

a. Literature studies, in the form of literature studies, studies of related books and electronic book journals (e-books).

b. Internet browsing, in the form of studies of articles, scientific journals, pictures and electronic books (e-books) as well as other data related to research

c. Field study method, namely by taking data from the results of tests carried out in the production process laboratory

d. Field study method, namely by taking data from the Mechanical Engineering laboratory located at the Master of Mechanical Engineering, University of North Sumatra

e. Discussion, in the form of questions and answers with the supervisor appointed by the Department of Mechanical Engineering, University of North Sumatra.

\section{RESULTS AND DISCUSSIONS}

\subsection{Experimental data analysis}

Three-channel and one-way divided flow heat exchanger with parallel flow configuration. This research was conducted using a three-layer tube type heat exchanger (triple concentric heat exchanger) with copper base, this triple concentric heat exchanger type has advantages compared to other types of heat exchangers, namely the ease of this tool to be opened and removed from the heat exchanger. the assembly to allow for better and easier cleaning and maintenance. Apart from that, this tool is also suitable for use for liquid fluids, because it has a wavy heat transfer surface that causes the turbulence of the fluid flow to be higher and automatically the heat transfer that occurs will be more effective.

\subsection{Mass flow rate analysis}

This test uses three types of velocity variations for three different fluid inlet temperature variations as well, to determine the mass flow rate of air in the pipe obtained from table 4.3 as follows:

Table 1. Density of fluid

\begin{tabular}{cc}
\hline $\mathrm{V}(\mathrm{m} / \mathrm{s})$ & $\varepsilon(\mathrm{m} 3 / \mathrm{s})$ \\
& \\
\hline 1.5 & 0.000025 \\
2.0 & 0.000033 \\
2.5 & 0.000041 \\
\hline
\end{tabular}




\subsection{Experimental data}

After calculating the above in all studies, the effectiveness data can be obtained in the following table:

Table. 2. Counterflow effectiveness

\begin{tabular}{|c|c|c|c|c|c|c|c|c|c|c|c|}
\hline \multirow{2}{*}{ Data } & \multirow{2}{*}{$\begin{array}{l}\text { Hot water } \\
\text { discharge } \\
\text { (LPM) }\end{array}$} & \multicolumn{2}{|c|}{ Hot Fluid } & \multirow{2}{*}{$\begin{array}{l}\text { Cold water } \\
\text { discharge } \\
\text { (LPM) }\end{array}$} & \multicolumn{4}{|c|}{ Cold Fluid } & \multirow[t]{2}{*}{$1(\%)$} & \multirow[t]{2}{*}{$2(\%)$} & \multirow[t]{2}{*}{$3(\%)$} \\
\hline & & Tinh1 & Touth2 & & Tinc1 & Tinc3 & Toutc1 & Toutc3 & & & \\
\hline 1 & & 49.43 & 33.71 & & 26.38 & 26.41 & 42.05 & 40.4 & 55.16 & 65.15 & 60.59 \\
\hline 2 & 1.5 & 55.51 & 26.32 & & 24.43 & 24.28 & 43.38 & 42.31 & 55.24 & 65.26 & 60.66 \\
\hline 3 & & 61.16 & 31.3 & & 25.04 & 25.32 & 47.66 & 46.74 & 56.29 & 66.61 & 62.04 \\
\hline 4 & & 49.72 & 27.65 & 1.5 & 25,13 & 25.32 & 43.44 & 40.62 & 59.94 & 69.66 & 63.95 \\
\hline 5 & 2.0 & 55.73 & 26.93 & & 25.46 & 25.5 & 43.98 & 41.41 & 60.05 & 69.83 & 64.13 \\
\hline 6 & & 60.13 & 33.11 & & 25.29 & 25.31 & 47.7 & 44.01 & 60.85 & 70.79 & 65.09 \\
\hline 7 & & 48.11 & 38.82 & & 25.2 & 26.11 & 45.33 & 43.24 & 63.67 & 73.47 & 67.13 \\
\hline 8 & 2.5 & 54.95 & 32.42 & & 25,24 & 25.49 & 47.47 & 44.57 & 63.61 & 73.15 & 66.64 \\
\hline 9 & & 60.07 & 34.48 & & 25.01 & 25,28 & 49.02 & 44.35 & 63.6 & 73.08 & 66.51 \\
\hline
\end{tabular}

From the table above, it can be seen that in the experiment the exit temperature $(T h, 0)$ and cold water temperature $(\mathrm{Tc}, 0)$ above, it can be seen that the lowest or maximum effectiveness of the APK is the 1 st data, which is $65 \%$ at the $\mathrm{m} 3 / \mathrm{s}$ discharge at hot water inlet temperature $(\mathrm{Th}, \mathrm{i})$ is $48.110 \mathrm{C}$ and hot water outlet temperature $(\mathrm{Th}, \mathrm{o})$ is $38.820 \mathrm{C}$ with a discharge of $0.00041 \mathrm{~m} 3 / \mathrm{s}$ and cold water temperature $(\mathrm{Tc}, \mathrm{i} 1)$ is $25.20 \mathrm{C}$ (Tci3) of $26.110 \mathrm{C}$ and exit temperature $(\mathrm{Tc} 1,0)$ of $45.33 \mathrm{oC}$, $(\mathrm{Tc} 3, \mathrm{o})$ of $43.24 \mathrm{oC}$ with a discharge of $0.000041 \mathrm{~m} 3 / \mathrm{s}$.

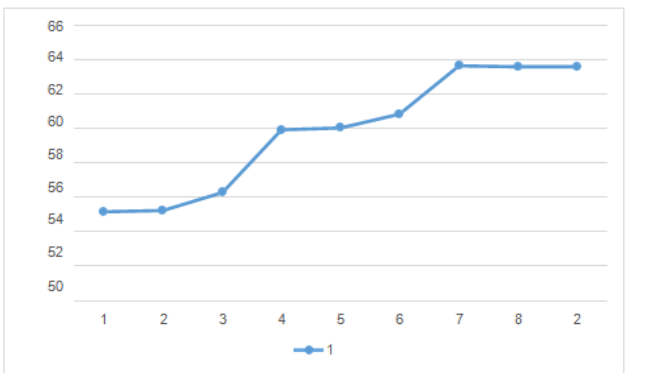

Figure: 1. Effectiveness Comparison Chart

From the graph above, it can be seen that the efficiency in one pipe is the lowest efficiency of $55.16 \%$ with a speed of $0.000025 \mathrm{~m} 3 / \mathrm{s}$ in the first experiment and the highest increase in efficiency of $63.67 \%$ at a speed of $0.000041 \mathrm{~m} 3 / \mathrm{s}$ in the 7 th experiment.

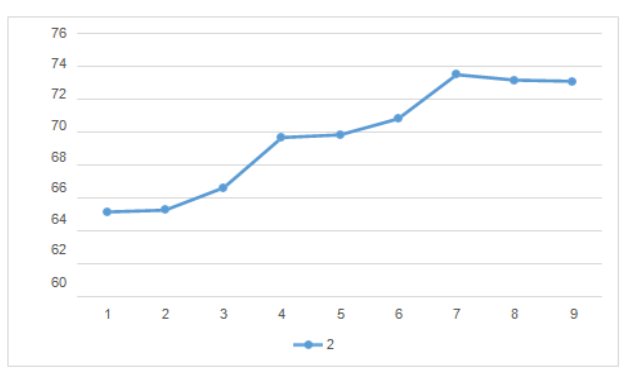

Figure 2. Effectiveness Comparison Chart

From the graph above, it can be seen that the efficiency of pipe one with the lowest efficiency is $65.15 \%$ with a speed of $0.000025 \mathrm{~m} 3 / \mathrm{s}$ in the first and second experiments. the highest increase in efficiency is $73.47 \%$ at a speed of $0.000041 \mathrm{~m} 3 / \mathrm{s}$ in the 7 th experiment 


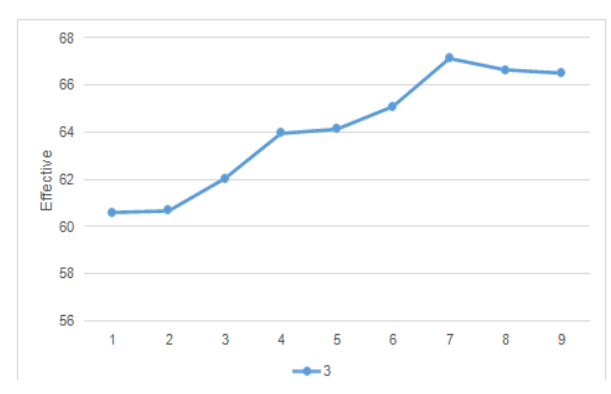

Figure 3. Effectiveness Comparison Chart

From the graph above, it can be seen that the efficiency in one pipe is the lowest efficiency of $64.59 \%$ with a speed of $0.025 \mathrm{~m} 3 / \mathrm{s}$ in the first experiment and the highest increase in efficiency is $67.13 \%$ at a speed of $0.000041 \mathrm{~m} 3 / \mathrm{s}$ in the 7 th experiment. in the comparison between effectiveness , , and in the counter-flow experiment the data on the effectiveness table are combined with the effectiveness and with the comparison table. The following is a comparison table of the effectiveness of , , and

Table 3. Counterflow effectiveness

\begin{tabular}{cccc}
\hline Data & & & \\
\hline 1 & 55.16 & 65.15 & 60.59 \\
2 & 55.24 & 65.26 & 60.66 \\
3 & 56.29 & 66.61 & 62.04 \\
4 & 59.94 & 69.66 & 63.95 \\
5 & 60.05 & 69.83 & 64.13 \\
\hline
\end{tabular}

The following is a comparison graph of the effectiveness of 1,2 and 3

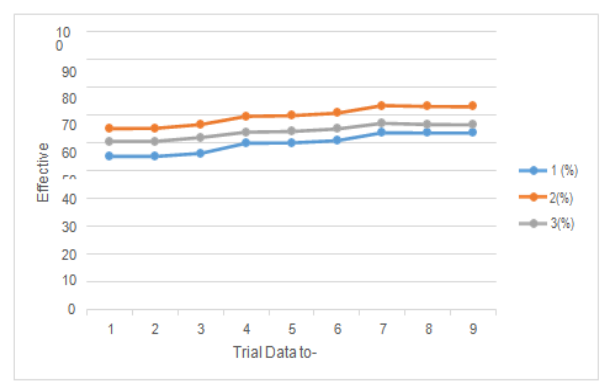

Figure 4. Comparison of effectiveness, and counter flow

From the graph above, it can be seen that both the experimental calculations obtained the effectiveness of the heat exchanger in the 3rd experiment. To facilitate the comparison between the effectiveness of, , and in the unidirectional and opposite flow experiments, the data in the effectiveness table are combined with the effectiveness and the table. comparison. The following is a comparison table of the effectiveness of , , and

Table 4. Comparison of direct flow and counter flow

\begin{tabular}{ccccccc}
\hline Data & \multicolumn{3}{c}{ Unidirectional Flow } & \multicolumn{3}{c}{ Opposite Flow } \\
& $\varepsilon_{1}(\%)$ & $\varepsilon_{2}(\%)$ & $\varepsilon_{3}(\%)$ & $\varepsilon_{1}(\%)$ & $\varepsilon_{2}(\%)$ & $\varepsilon_{3}(\%)$ \\
1 & 32.89 & 66.45 & 33.55 & 55.16 & 65.15 & 60.59 \\
\hline
\end{tabular}




\begin{tabular}{lllllll}
\hline 2 & 32.9 & 66.46 & 33.57 & 55.24 & 65.26 & 60.66 \\
3 & 32.99 & 66,48 & 33.57 & 56.29 & 66.61 & 62.04 \\
4 & 39.67 & 59.86 & 40.15 & 59.94 & 69.66 & 63.95 \\
5 & 39.76 & 59.88 & 40,12 & 60.05 & 69.83 & 64.13 \\
6 & 39.82 & 59.89 & 40,12 & 60.85 & 70.79 & 65.09 \\
7 & 44.93 & 54.87 & 40.11 & 63.67 & 73.47 & 67.13 \\
8 & 44.93 & 54.87 & 45,13 & 63.61 & 73.15 & 66.64 \\
\hline
\end{tabular}

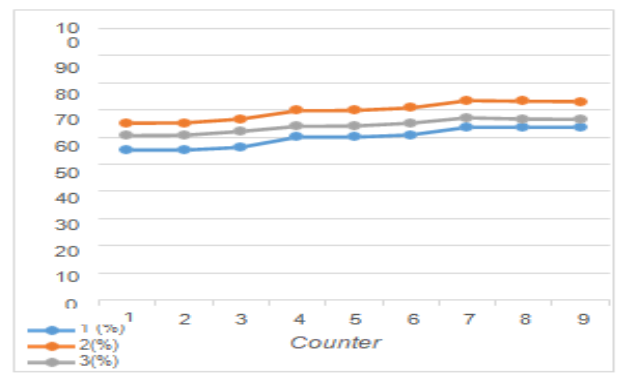

Figure 5. Comparison Graph of the Effectiveness of Parallel flow and Counter flow

Unidirectional flow from the graph above, it can be seen that in the experiment the exit temperature $(T h, 0)$ and cold water temperature $(T c, 0)$ above, it can be seen that the highest effectiveness of the direct flow APK is the 3rd data, which is $2=66.48 \%$ with The fluid velocity rate is $0.000025 \mathrm{~m} 3 / \mathrm{s}$ while the opposite flow from the graph above is obtained below in the experimental exit temperature $(T h, 0)$ and cold water temperature $(T c, 0)$ above, it can be seen that the highest effectiveness of the APK is the 7th data, which is equal to $273.47 \%$. Then the effectiveness of the highest APK in the graph above is the 7th opposite flow, which is $2=73.47 \%$

\section{CONCLUSION}

The average inlet temperature in each pipe of the heat exchanger with experimental direct flow at a temperature of $60 \mathrm{oC}$ and a flow rate of $0.000025 \mathrm{m3} / \mathrm{s}$ is TinC $1=25.490 \mathrm{C}$, Tinh2 $=60.70 \mathrm{C}$, TinC3 $=$ $25.030 \mathrm{C}$ and the flow opposite temperature at $50 \mathrm{oC}$ and flow rate $0.000041 \mathrm{m3} / \mathrm{s}$ is $\mathrm{TinC} 1=25.2 \mathrm{oC}$, Tinh2 $=48.110 \mathrm{C}$, TinC3 $=26.110 \mathrm{C}$

The average exit temperature of each unidirectional heat exchanger pipe at a temperature of $60 \mathrm{oC}$ and a flow rate of $0.000025 \mathrm{~m} 3 / \mathrm{s}$ is ToutC $1=43.52 \mathrm{oC}$, Touth $2=33.080 \mathrm{C}$, ToutC $3=42.5 \mathrm{oC}$ and counter flow at temperature $50 \mathrm{oC}$ flow rate $0.000041 \mathrm{~m} 3 / \mathrm{s}$ is ToutC $1=45.33 \mathrm{oC}$, Touth2 $=$ $38.82 \mathrm{oC}$, ToutC3 $=43.24 \mathrm{oC}$

The highest effectiveness of pipelines one, two and three heat exchangers experimentally at a temperature of $550 \mathrm{C}$ with a speed of $0.000025 \mathrm{~m} 3 / \mathrm{s}$ direct flow $1=32.99 \%, 2=66.48 \%$ and $3=$ $33.57 \%$ and while the flow opposite $1=55.16 \%, 2=65.15 \%$ and $3=60.59 \%$ with a velocity of $0.000041 \mathrm{~m} 3 / \mathrm{s}$ at a temperature of $60 \mathrm{oC}$.

\section{REFERENCES}

Cengel, Y. A. 2006. Thermodynamics An Engineering Approach,Edition.

Incropera, F. P, dkk. Fundamentals of Heat and Mass Transfer, Edition. New York : John Wiley \& Sons

Luqman Buchori, ST, MT Perpindahan Panas Heat Transfer edisi ke-2 Universitas Gadjah Mada, Yogyakarta, 2005. 
Gulta, J.P 1986 Working With Heat and Exchangers, Edition. Entiled Fundamentals of heat exchanger and pressure vessel teknologi.

Fatimah, Siti. Analisis elevasi aliran air pendingin kondensor terhadap laju perpindahan kalor dan efisiensi kerja mesin. Diss. Universitas Islam Negeri Maulana Malik Ibrahim, 2008.

Anowar Hossain, Md. 2017. Experimental Analysis of a Triple Concentric Tube Heat Exchanger. Jurnal. Universitas, Gazipur, Bangladesh.

Aprilino, Kurnia lqbal. PENGARUH KECEPATAN ALIRAN TERHADAP EFISIENSI ALAT PENUKAR PANAS (EFFECT OF FLOW RATE TO EFFICIENCY OF HEAT EXCHANGER). Diss. UNDIP, 2016.

Cengel, Yunus.A. 2003. Heat Transfer: A Practical Approach, ed. New York : McGraw-Hill.

Pardede, A. R. O. (2016). Analisis Penggantian Pre-Cooler Untuk Turbin Gas (Studi Kasus Pada PLTG 3 Alstom di PT PT. PLN (Persero) Sektor Keramasan, Palembang, Sumatera Selatan) (Doctoral dissertation, Institut Teknologi Sepuluh Nopember).

Holman, J. P. 1997. Heat Transfer, Edisi ke-10. Jakarta :Erlangga.

Hidayatullah, Reza, and Bambang Arip Dwiyantoro. "Studi Numerik Pengaruh Baffle Inclination Pada Alat Penukar Kalor Tipe U-Tube Terhadap Aliran Fluida Dan Perpindahan Panas." Jurnal Teknik ITS 3.2 (2014): B198-B203.

Kuppan, T. 2000. Heat Exchanger Design Handbook, Second Edition.Newyork : Marcel Dekker.Inc

Munson, Bruce R. 1997. Mekanika Fluida, edisi ke-2. Jakarta : Erlangga.

Kreith, Frank. 1877. Principles Of Heat Transfer, ed. New York : Harper and Row.

Pitts, Donald. 2008. Perpindahan Kalor, edisi ke-2. Erlangga :2108

Hundry, G. F., A. R. Trott, T. C. Welch. Tanpa Tahun. Refrigeration and Air Conditioning - Fourth Edition. B.H.

W.J. Minkowycz and J.P Hartnett Efektiveness-NTU Relations For Triple Concentric-Tube Heat Exchanger. Trabzon, Turkey. 